\title{
Analysis of Determining Service Recovery Factors at Super Indo Grocery Store in Semarang
}

\author{
Jefri Heridiansyah $^{1}$, Theresia Susetyarsi ${ }^{1}$, Ariyani Indriastuti ${ }^{1} \&$ Frida Widyawati Triasningrum ${ }^{1}$ \\ ${ }^{1}$ Lecture in STIE Semarang, Indonesia \\ Correspondence: Jefri Heridiansyah, STIE Semarang, Central Java, Indonesia. E-mail: jefri@stiesemarang.ac.id
}

Received: February 5, 2021

Accepted: March 5, 2021

Online Published: March 15, 2021

doi:10.5539/ijef.v13n4p57

URL: https://doi.org/10.5539/ijef.v13n4p57

\begin{abstract}
The purpose of this study was to determine: (1) How big effect of the Service Failure on Service Recovery at Super Indo Grocery Store in Semarang? (2) How big effect of the Customer Complaint on Service Recovery at Super Indo Grocery store in Semarang? The sample in this study amounted to 40 respondents or customers. This study was analyzed using multiple linear regression which included the T-Test, F Test, and the coefficient of determination. Based on the results of research and discussions that have been carried out, it can be concluded that there is an effect of Service Failure on Service Renewal is an influence of Customer Complaint on Service Recovery.
\end{abstract}

Keywords: service failure, customer complaint, service recovery

\section{Introduction}

During booming shopping centers such as malls, shops, markets, and so on, especially in big cities, the high level of competition in acquiring customers is inevitable. Such conditions must be a concern for store managers to find solutions in the face of intense competition. In this case, it is necessary if you want your business to be sustainable and even grow.

Super Indo, as one of the grocery stores that have businesses in the field of shopping for daily needs, must be able to answer the challenges in the competition so retain and increase its customers. Therefore, Super Indo must be able to provide satisfaction for the customers who visit it. Satisfied customers will refer to prospects they know and vice versa dissatisfied customers will share their bad experiences with others and decide to leave the company (Mattila, 2001). Disappointed customers must be responded quickly by the company by improving the service quality. Appropriate service recovery can be the main strategy to achieve customer satisfaction and loyalty (Tax \& Brown, 1998). Through service recovery, the company can regain customer trust (Kelley et al., 1993).

Through service recovery effetiveness, customer disappointment can be minimized so that customer satisfaction can be acceptable. Successful service recovery will have a positive impact on customer satisfaction after service recovery and the intended consumption of future services (Spreng et al., 1995) and consumer loyalty to the company (Levesque \& McDougal, 2000). Satisfaction with dissatisfaction is the result of a comparison between customer expectations and perceptions of services that are felt or provided. If customer expectations are under the perception, it can say that there is conformity while expectations do not match the perception and will be a discrepancy.

Based on the background described above, the main issues that will be clarified discussed in this study are:

1) Does Service Failure affect Service Recovery at Super Indo Semarang?

2) Does Customer Complaint affect Service Recovery at Super Indo Semarang?

\section{Method}

\subsection{Service Recovery}

Service Recovery is carried out by companies to correct mistakes and regain customer trust (e.g. Kelley et al., 1993). Successful service recovery will have a positive influence on post-service satisfaction and the purpose of purchasing goods again or future service consumption (Spreng et al., 1995). 
There are several different definitions of researchers regarding Service Recovery based on Zeithaml and Bitner (2002, p. 166) "Service Recovery refers to actions taken by an organization in response to a service failure". Meanwhile, according to Hoffman and Bateson (2017, p. 364) stated that: Service Recovery is a firm's reaction to a complaint that results in customer satisfaction and goodwill.

\subsection{Service Failure}

According to Hoffman and Bateson (2017, p. 352), Service Failure is a breakdown in the delivery of service; service that those don't meet the customer expectations. It can be an interpretation that service failure is a setback in the delivery of services or other words, services that do not meet consumer expectations. The size of the error rate in service delivery can vary (Kelley \& Davis, 1994) depending on each person and situation (Hart et al., 1990).

Complaints are gifts from customers, not a threat to the company (Barlow, 2000). Customers who complain can turn into loyal customers if the company can handle these complaints properly (Cannie, 1994).

\subsection{Customer Complaint}

One effort to be able to retain customers is by handling complaints. Handling complaints can have a positive impact on customer satisfaction because customers who complain can turn into loyal customers if the company can handle complaints properly (Cannie, 1994).

In the context of service management, various definitions can be used to give a sense of complaint, complaining, according to Hoffman and Beteson (2017, p. 362): Expressing discontent, dissatisfaction, protest, resentment, or regret. "This means that Complaining is an expression of dissatisfaction, protest, irritation, or regret.

According to Lovelock (1994, p. 61) that: Complain data are the key in quality management efforts because they can be used to correct problems with service design and delivery, which makes it more likely that performance will be right the first time. It means that handling complaints is the key to improving the quality of management because they can be used to correct mistakes by sending, which allows work to complete on time.

\subsection{Framework}

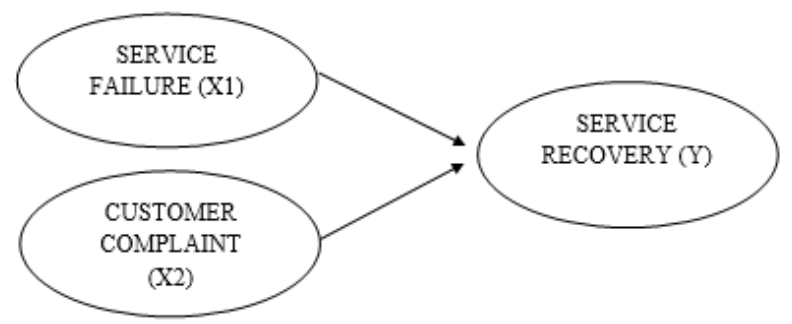

Figure 1. Framework scheme

\subsection{Hypothesis}

Based on the formulation of the problem that has determined, the hypotheses proposed in this study are as follows:

H1: Service Failure affects Service Recovery at Super Indo Semarang.

H2: Customer Complaint influences Service Recovery at Super Indo Semarang

\section{Method}

This type of research is the quantitative research that distributes questions in the form of questionnaire questions to consumers or customers of Super Indo in Semarang. The population is all consumers or customers who have complained about Super Indo services in Semarang. In this study, the sample used was 40 respondents. This study uses primary data collected using a questionnaire instrument. Besides, this study also uses interview techniques and secondary data in the form of relevant literature.

\section{Results}

\subsection{Multiple Linier Regression Analysis}

Multiple linear regression analysis is to answer the hypothesis that has been proposed by the researcher to determine the influence of independent or free variables, namely Service Failure and Customer Complaint on Service Recovery. 
Table 1. Multiple linier regression analysis

\begin{tabular}{|c|c|c|c|c|c|c|}
\hline \multicolumn{7}{|c|}{ Coefficients $^{\mathrm{a}}$} \\
\hline & & Unsta & Coefficients & Standardized Coefficients & & \\
\hline \multicolumn{2}{|c|}{ Model } & B & Std. Error & Beta & $\mathrm{t}$ & Sig. \\
\hline & (Constant) & 1,859 & ,769 & & 1,118 & ,003 \\
\hline & Service Failure & ,586 & 067 & ,656 & 8,680 & 000 \\
\hline & Customer Complaint & ,368 & ,074 & ,374 & 4,948 & 000 \\
\hline
\end{tabular}

a. Dependent Variable: Service Recovery, 2020.

The equation for multiple linear regression analysis is: $\mathrm{Y}=1.859+0.586(\mathrm{X} 1)+0.368(\mathrm{X} 2)$ Based on this equation, it can be described as follows:

1) If the independent variables, namely Service Failure and Customer Complaint, are zero, the average Service Recovery rate will remain at 1.859 .

2) The regression coefficient for the independent variable (X1) is positive, indicating a unidirectional influence between Service Failure (X1) and Service Recovery (Y). The variable regression coefficient (X1) is 0.586 means that for each additional, it will cause an increase in Service Recovery at Super Indo in Semarang.

3) The regression coefficient for the independent variable (X2) is positive, indicating a unidirectional influence between Customer Complaint (X2) and Service Recovery (Y). The variable regression coefficient (X2) of 0.368 implies that for each unit increment will cause an increase in Service Recovery at Super Indo in Semarang

4.2 T-Test

Table 2. T-Test

\begin{tabular}{|c|c|c|c|c|c|}
\hline \multicolumn{6}{|c|}{ Coefficients $^{\mathrm{a}}$} \\
\hline \multirow[b]{2}{*}{ Model } & \multicolumn{2}{|c|}{ Unstandardised Coefficients } & \multirow{2}{*}{$\begin{array}{c}\text { Standardized Coefficients } \\
\text { Beta }\end{array}$} & \multirow[b]{2}{*}{$\mathrm{t}$} & \multirow[b]{2}{*}{ Sig. } \\
\hline & $\mathrm{B}$ & Std. Error & & & \\
\hline 1 (Constant) & 1,859 & ,769 & & 1,118 & ,003 \\
\hline Service Failure &, 586 &, 067 &, 656 & 8,680 &, 000 \\
\hline Customer Complaint & ,368 &, 074 &, 374 & 4,948 &, 000 \\
\hline
\end{tabular}

a. Dependent Variable: Service Recovery, 2020.

Testing variable X1 explained that; Service Failure to Service Recovery is Ho: b1 <0 and Ha: b1>0 with a significant level of 0.05 . After the analysis, the $T$ value then calculates Service Failure (8.680) $>t$ table (1.686) and a significance value of $0.000<0.05(5 \%)$, then Ho is rejected, Ha is accepted, which means that there is a positive and significant influence between Service Failure on Service Recovery. The conclusion of hypothesis 1 is accepted.

Testing the X2 variable can be explained that; Customer Complaint on Service Recovery, namely Ho: b2 <0 and Ha: b2>0, and the real level is 0.05. After analyzing the $t$ value is obtained Customers Complaint $(4,948)>t$ table $(1,686)$ and a significance value of $0,000<0.05(5 \%)$, then Ho is rejected, Ha is accepted. It means that there is a positive and significant influence between Customer Complaint on Service Recovery. The conclusion of hypothesis 2 is accepted.

\subsection{F-Test}

The feasibility test of the model seems with the results of the F test. The feasibility test of the model used to test whether the linear model is correct or not, then it is seen by comparing the probability from the results of the $\mathrm{F}$ test. When it shows a probability value $<0.05$, the model in the regression is a model that fits. Following are the results of the F test: 
Table 3. F-test

\begin{tabular}{llccccc}
\hline \multicolumn{1}{c}{ ANOVA $^{\mathrm{a}}$} & & \\
\hline Model & Sum of Squares & Df & Mean Square & F & Sig. \\
\hline 1 & Regression & 77,473 & 2 & 38,736 &, $000^{\mathrm{b}}$ & \\
& Residual & 11,902 & 37 & 322 & & \\
& Total & 89,375 & 39 & & \\
\hline
\end{tabular}

a. Dependent Variable: Service Recovery.

b. Predictors: (Constant), Customer Complaint, Service Failure, 2020.

Based on table 3, the value of F calculated is F count: 20.417> F table 3.24 with a significance level of 0.000 $<0.05$. So it can be concluded that the model is a fit model

\subsection{The Coefficient of Determination}

The coefficient of determination that essence is to measure how far the ability of the model on the Independent Variable (X) to explain the Bound Variable (Y) (Ghozali, 2006). The following is the result of the coefficient of determination (R2):

Table 4. The coeeficient of Determination

\begin{tabular}{ccccc}
\hline \multicolumn{5}{c}{ Model Summary } \\
\hline Model & R & R Square & Adjusted R Square & Std. Error of the Estimate \\
\hline 1 &, $931 \mathrm{a}$ &, 867 &, 860 &, 567 \\
\hline
\end{tabular}

a. Predictors: (Constant), Customer Complaint, Service Failure, 2020.

The coefficient of determination (R2) of 0.860 means that $86.0 \%$ of the variation in changes in the dependent variable (Service Recovery) can be explained by the independent variable (Service Failure and Customer Complaint), while $14.0 \%$ of the condition of the dependent variable (Y) is explained by other independent variables. not monitored in research such as marketing mix variables, customer retention, and other variables that are considered relevant.

\section{Discussion}

According to the research results and discussions, it mentions the Analysis of Determining Factors for Service Recovery at the Super Indo grocery shop in Semarang, namely that there is a positive and significant influence between Service Failure and Customer Complaint on the Service Recovery variable. The results of statistical tests show that there is a positive and significant influence between Service Failure and Service Recovery with the $t$ value of Service Failure $(8,680)>t$ table $(1,686)$ and a significance value of $0,000<0.05(5 \%)$. However, for Customer Complaints on Service Recovery, the t value is Customer Complaint (4.948)> t table (1.686) and a significance value of $0.000<0.05(5 \%)$, meaning that there is a positive and significant influence between Customer Complaint on Service Recovery.

\section{Suggestion}

The results of this study bring many suggestions for managerial Superindo, in the form of proposed strategies (ways) that can be done in improving Service Recovery are as follows: Companies should provide better services than competitors; The company provides value that is superior to competitors, so that customers do not move to other companies. The company provides several quality services, which are not provided by competitors, but this must be accompanied by providing several compensation facilities for employees in carrying out their work; and the Company provides additional services that are unique and beneficial to customers, resulting in repeated purchases that can ultimately increase Superindos' revenue.

Concerning the influence of Service Errors on the Improvement of Super Indo Services, in principle customers who complain expect an improvement over mistakes made by Super Indo, and a good response in Service Recovery can restore customer confidence, and make them loyal to Superindo.

About the influence of Customer Complaints on the Improvement of Superido Services. Superindo's response to customer complaints can make them loyal to Superindo, thereby Superindo has the opportunity to recover Service Recovery. 


\section{References}

Arikunto, S. (1998). Prosedur Penelitian Suatu Pendekatan Praktik (9th ed.). Jakarta: Rineka Cipta.

Barlow, D. H. (2000) Unraveling the mysteries of anxiety and its disorders from the perspective of emotion theory. American Psychologist, 55(11), 1247-1263. https://doi.org/10.1037/0003-066X.55.11.1247

Bateson, \& Douglas, H. K. (2017). Services Marketing: Concepts, Strategies \& Cases (7th ed.). USA Cengage Learning.

Fitzsimmons, J. A., \& Fitzsimmons, M. J. (2001). Services Management for Competitive Advantage. USA: McGraw Hill International Editions.

Ghozali, I. (2005). Aplikasi Analisis Multivariate Dengan Program SPSS. Semarang: Badan Penerbit Universitas Diponegoro.

Hadi, S. (1990). Metodologi Research 2. Yogyakarta: Andi Offset.

Indrawijaya, A. I. (1983). Compensation Management: Rewarding Performance (3rd ed.). Virginia: Prentice Hall Company.

Indriantoro, N., \& Bambang, S. (2009). Metodologi Penelitian Bisnis untuk Akuntansi dan Manajemen (1st ed.). Yogyakarta: BPFE Yogyakarta.

Irawan, H. (2002). 10 Prinsip Kepuasan Pelanggan. Jakarta: PT Elex Media Komputindo.

Kelley, S. W., Hoffman, K. D., \& Davis, M. A. (1993). A typology of retail failures and recoveries. Journal of Retailing, 69(4), 429-452. https://doi.org/10.1016/0022-4359(93)90016-C

Larzelere, R. E., \& Huston, T. L. (1980). The dyadic trust scale: Toward understanding interpersonal trust in close relationships. Journal of Marriage and the Family, 42(3), 595-604. https://doi.org/10.2307/351903

Mattila, A. S. (2001). The Effectiveness of Service Recovery in A Multi-Industry Setting. Journal of Services Marketing, 15(7), 583-596. https://doi.org/10.1108/08876040110407509

McDougall, G. H. G., \&Levesque, T. (2000). Customer satisfaction with services: Putting perceived value into the equation. Journal of Services Marketing, 14(5). 392-410. https://doi.org/10.1108/08876040010340937

Richard, A. S. (1995). Service Recovery: Impact on Satisfaction and Intentions. Journal of Services Marketing, 9(1), 15-23. https://doi.org/10.1108/08876049510079853

Santoso, S. F., \& Tjiptono. (2001). Riset Pemasaran: Konsep dan Aplikasi dengan SPSS. Jakarta: Gramedia.

Sugiyono. (2000). Metode Penelitian Bisnis. Bandung: Alfabeta.

Tax, S. S., Brown, S. W., \& Chandrashekaran, M. (1998). Customer Evaluations of Service Complaint Experiences: Implications for Relationship Marketing. Journal of Marketing, 62, 60-76. https://doi.org/10.2307/1252161

Terrence J. L, \& Gordon H. G. M. (2000). Service Problems and Recovery Stratégies: An Experiment. $\begin{array}{lllll}\text { Canadian Journal of } \quad \text { Administrative } & \text { Sciences, } & 17(1), & 20-37 .\end{array}$ https://doi.org/10.1111/j.1936-4490.2000.tb00204.x

Zeithaml, V. A., \& Mary, J. B. (2002). Essentials of Services Marketing: Integrating Customer Focus Across The Firm (2nd ed.). Irwin: McGraw Mill, Inc

\section{Copyrights}

Copyright for this article is retained by the author(s), with first publication rights granted to the journal.

This is an open-access article distributed under the terms and conditions of the Creative Commons Attribution license (http://creativecommons.org/licenses/by/4.0/). 